\title{
Post-transfusion hepatitis in a London hospital: results of a two-year prospective study
}

\author{
A Report to the M.R.C. Blood Transfusion Regearch Committee by the \\ Medical Research Council Working Party on \\ Post-Transfusion Hepatitis*
}

(Received 21 February 1974)

\section{SUMMARY}

Seven hundred and sixty-eight patients were seen and tested at frequent intervals after transfusion of whole blood. Eight patients were judged to have developed icteric or anicteric post-transfusion viral hepatitis, an incidence of $1 \%$. Five were icteric and four of these were hepatitis $\mathrm{B}$ antigen ( $\mathrm{HB} \mathrm{Ag}$ ) positive; two of these four died. One of the fatal cases and one non-fatal $\mathrm{HB} \mathrm{Ag}$ positive case had received HB Ag positive blood. Two other antigen-positive patients had received blood or plasma or both which had not been tested for antigen.

Thirty-five patients showed conspicuous or sustained elevations of alanine transaminase without clinical features of hepatitis.

Four were positive for HB Ag but had not received antigen positive blood.

Two who had received antigen positive blood remained antigen negative, but one developed hepatitis B antibody (HB Ab).

Two other patients were also transfused with plasma.

Five had serological evidence of cytomegalovirus (CMV) infection accompanying the enzyme changes.

One patient who had received $\mathrm{HB} \mathrm{Ag}$ positive blood remained antigen-negative and showed no abnormalities.

Five patients who became HB Ag positive, although they had been given antigen-negative blood, remained clinically and biochemically well.

Cytomegalovirus primary infection or reactivation occurred in another 32 patients; five had isolated, transient enzyme rises, one other was associated with a drug-induced focal liver necrosis and 26 showed no enzyme changes. Epstein-Barr virus infections, one of which was associated with a transient upset of enzyme activity, were detected in five patients. There were no cases of post-perfusion syndrome.

\section{INTRODUCTION}

Hepatitis of viral origin is a major public health problem throughout the world. It constitutes the main hazard of the transfusion of blood and the use of blood products apart from immunoglobulin and preparations of albumin. There are no reliable biochemical or histological features to help distinguish between type $A$ (infectious) hepatitis and type B (serum) hepatitis. Both types of infection may be

* Requests for reprints should be addressed to Professor A. J. Zuckerman, London School of Hygiene and Tropical Medicine, Keppel Street, London WC1E 7HT. 
transmitted by blood transfusion and the term post-transfusion hepatitis includes both types. The clinical range includes inapparent infection, anicteric illness, acute icteric disease of varying severity and chronic liver damage.

A high incidence of post-transfusion icteric and anicteric hepatitis was reported between 1963 and 1970 in the United States of America, Germany and Japan (literature reviewed by Zuckerman, $1970 a$ and 1972). No data for the incidence of icteric post-transfusion hepatitis in the United Kingdom more recent than 1954 are available and the frequency of anicteric post-transfusion hepatitis has not been previously investigated in this country apart from a small survey in Birmingham (Somayaji, Stone \& Glover, 1967).

The discovery of a serum antigen associated with human hepatitis (Blumberg et al. 1967; Prince, 1968), now known as hepatitis B antigen (HB Ag), provided a serological marker for recognizing infection with or carriage of the virus of type $B$ hepatitis. A test for $\mathrm{HB} \mathrm{Ag}$ is now used to screen donor blood thereby reducing the incidence of transfusion hepatitis (McCollum \& Zuckerman, 1970). Cytomegalovirus (CMV) and perhaps also Epstein-Barr virus (EBV) have recently been recognized as other possible causes of post-transfusion hepatitis (Paloheimo et al. 1968; Henle et al. 1970).

The two-year survey here reported was undertaken at the Central Middlesex Hospital, London, N.W.10, which serves a mixed population of about 250000 people. Approximately 4500 units of ACD blood, stored at $4^{\circ} \mathrm{C}$., are used annually at this hospital, all of which are obtained from voluntary unpaid donors by the North London Blood Transfusion Centre, Edgware. Patients were studied intensively both clinically and by laboratory tests for liver function for 6 months after blood transfusion. The survey began on 1 July 1969 and the clinical follow-up of the last patient was completed on 31 December 1971. The objects of the survey were:

1. To obtain information about the incidence of icteric and anicteric posttransfusion hepatitis.

2. To establish the frequency of hepatitis $\mathrm{B}$ antigen ( $\mathrm{HB} \mathrm{Ag}$ ) and the corresponding antibody $(\mathrm{HB} \mathrm{Ab})$ in blood donors and patients and to try to correlate their presence with blood transfusion and its complications.

3. To determine the frequency of transmission of EBV and CMV by blood transfusion and their role in causing post-transfusion liver damage.

\section{Patients and controls}

\section{METHODS}

All patients aged between 16 and 75 years who were transfused with whole blood at the Central Middlesex Hospital between 1 July 1969 and 30 June 1971, were invited to participate, after a full explanation of the purpose of the survey and the methods to be used. A pretransfusion blood sample was obtained for alanine transaminase (ALT) estimations and virological studies. Patients were seen at 2-weekly intervals for 3 months after transfusion and monthly for the next 3 months. Blood samples were obtained on each occasion.

At the initial interview a full history was obtained with particular reference to 
previous jaundice, hepato-biliary disease and transfusion. Any history of injections, dental procedures, exposure to jaundiced persons and travel outside the United Kingdom within the 6 months before transfusion was noted. Details of alcohol consumption and all drugs being administered were noted; the illness necessitating hospital admission, and the nature of any anaestheties given, were documented. Serial numbers of units of blood administered and where relevant those of other blood products were recorded. Defaulters who failed to respond to postal or telephone reminders were visited at home when possible.

At each follow-up visit patients were again questioned about these points and about possible symptoms of hepatitis. They were also clinically examined on each occasion. The serum ALT activity was measured at each visit. Patients with raised serum ALT values were recalled in order to confirm the abnormality, and measurements of serum bilirubin, van den Bergh reaction, alkaline phosphatase and bromsulphthalein (BSP) retention were carried out. If, as a result of these tests, hepatitis was suspected, haemoglobin, blood film, white blood cell count and differential, platelet count, prothrombin time and erythrocyte sedimentation rate were also studjed. Patients with a confirmed serum ALT abnormality, together with either abnormal BSP retention or symptoms or signs suggesting hepatitis, were considered candidates for liver biopsy. Biopsy was never performed without informed consent by the patient. In addition the permission of the consultant in charge of the case, or of the general practitioner, was obtained. Biopsy specimens were processed for light microscopy by routine methods. Patients with confirmed hepatitis were seen frequently and treated according to conventional practice.

Initially, it was intended that the transfused patients would act as their own controls, since pre-transfusion biochemical and serological data were obtained from each patient. However, certain of the early results of tests for the presence of $\mathrm{HB} \mathrm{Ag}$ and $\mathrm{HB} \mathrm{Ab}$ indicated the need for untransfused controls. An attempt was made to follow a group of untransfused patients matched for age and sex with those transfused, at less frequent intervals for 6 months. After recruitment of 200 such controls this attempt was abandoned because it proved impossible to persuade the subjects to attend regularly for examination. Instead, untransfused patients aged between 16 and 75 years who had been in-patients during the preceding 6 months were randomly studied when they re-attended the out-patient department. A single blood specimen was obtained from each of them during the period 1 February to 30 November 1971. Although each patient gave only one sample, the total control group provides a range of specimens spanning a 6-month post-admission period. $\mathrm{HB} \mathrm{Ag}$ and $\mathrm{HB} \mathrm{Ab}$ tests were performed on all these specimens, but since paired sera were not available, CMV and EBV antibody studies were not done. It is appreciated that the design of the control series was a compromise.

\section{Blood specimens}

At each visit $20 \mathrm{ml}$. blood were collected in a sterile container and allowed to clot at room temperature. Specimens were centrifuged at $4^{\circ} \mathrm{C}$. and the serum 
distributed aseptically into sterile $3 \mathrm{ml}$. screw-capped vials. Serum for ALT estimation was stored for a maximum of $48 \mathrm{hr}$. at $4^{\circ} \mathrm{C}$.; serum for virological studies was stored at $-20^{\circ} \mathrm{C}$.

\section{Biochemical methods}

Alanine transaminase was estimated by the 'optimal' method of Bergmeyer \& Bernt (1963) with a Unicam SP 800 A recording spectrophotometer. The decrease in optical density at $340 \mathrm{~nm}$. for $5 \mathrm{~min}$. at $30^{\circ} \mathrm{C}$. was recorded. The results were expressed as International Units (iu) per litre at $25^{\circ} \mathrm{C}$., using a conversion factor of 0.723 . Reproducibility of the test and activity of the reagents were determined daily with a commercially available control serum before and after every batch of tests (Chemonitor II, Dade Laboratories, Miami). The method is known to give values notably higher than those obtained by commonly used methods with suboptimal substrate concentrations (Giusti, Ruggiero \& Cacciatore, 1969). The enzyme values obtained in transfused patients had a log-normal distribution. Values greater than 30 i.u. were regarded as abnormal. For administrative reasons it was occasionally necessary to measure the serum ALT by an automated version of the colorimetric method of Reitman \& Frankel (1957). Values greater than $40 \mathrm{Karmen}$ units were regarded as abnormal.

Total serum bilirubin was measured by the Technicon Laboratory Auto-Analyzer method $\mathrm{N} 12$ (normal values $<0.8 \mathrm{mg} . / 100 \mathrm{ml}$.).

Total serum alkatine phosphatase was measured by the method of Bowers \& $\mathrm{McComb}$ (1966) using a Pye Unicam recording spectrophotometer at $30^{\circ} \mathrm{C}$. (normal value $<110$ i.u./1.).

Bromsulphthalein ( $B S P$ ) retention was measured $45 \mathrm{~min}$. after intravenous injection of $5 \mathrm{mg}$. BSP per kilogram of body weight (normal value $<5 \%$ retention at $45 \mathrm{~min}$.).

\section{Virological studies}

Tests for $H B A g$ and $H B A b$. Immunodiffusion tests were carried out as described by Zuckerman \& Taylor (1969) by the double diffusion micro-Ouchterlony technique as modified by Prince (1968). Agarose gel (0.9\%) was prepared in a buffer containing $0 \cdot 1 \mathrm{~m}$ sodium chloride, $0 \cdot 1 \mathrm{~m}$ tris (hydroxymethyl) amino-methanol ( $\mathrm{pH} 7 \cdot 6$ at $25^{\circ} \mathrm{C}$.), $0.001 \mathrm{~m}$ ethylenediamine-tetra-acetic acid, and $1 \mathrm{mg} . / \mathrm{ml}$. protamine sulphate. Merthiolate was added to the gel to give a final concentration of 1/5000. Tests were performed in $190 \mathrm{~mm}$. Sterilin plastic Petri dishes containing $15 \mathrm{ml}$. of $0.9 \%$ agarose gel. A pattern of six equivalent wells surrounding a central well was used. The wells were $2.5 \mathrm{~mm}$. in diameter and $4 \mathrm{~mm}$. apart. Test sera were added to the peripheral wells and allowed to diffuse for $20 \mathrm{~min}$. before adding antiserum to the central well. The gel was kept in a moist chamber at room temperature and read daily for 7 days. The antiserum was human plasma containing $\mathrm{HB} \mathrm{Ab}$; it gave reactions of immunological identity with other laboratory reference antisera and was subsequently shown to possess the specificity ad. A known HB Ag positive control human plasma was included in every plate; recently, this was also shown to carry the determinant ad. Each positive precipitin reaction was checked 
for immunological identity by immunodiffusion and confirmed by complement fixation (Taylor, 1970) and, sometimes, by electron microscopy (Zuckerman, $1970 b$ ). All the specimens are now being re-examined by radioimmunoassay and the results will be published in due course.

\section{Serological tests for cytomegalovirus (CMV) and Epstein-Barr virus (EBV) antibodies}

The first (pre-transfusion) and final (tenth) serum specimens from each patient were examined simultaneously for CMV and EBV antibodies. Whenever a test showed the appearance of antibodies in a previously sero-negative patient, or a fourfold increase in the titre of pre-existing antibody, the intermediate serum specimens from the patient were then examined together with the first and tenth specimens in a single test in order to determine the time of the antibody conversion or booster response. Sera were examined for cytomegalovirus complement-fixing antibodies by the micro-titre technique, using unheated, cell-associated antigens prepared from the AD 169 strain of virus (Stern \& Elek, 1965). EBV antibodies were estimated by the indirect immunofluorescent technique, using EB3 Burkitt tumour cells (Epstein, Achong \& Barr, 1964), which had been maintained on an arginine-deficient medium for 5 days before use, and fluorescein-conjugated antihuman IgG globulin (Wellcome Laboratories) (Henle \& Henle, 1966; Henle, Henle \& Diehl, 1968).

\section{RESULTS}

Between 1 July 1969 and 30 June 1971, 2184 patients were transfused. Of these, 489 were outside the accepted age limits and 443 were omitted for other adequate reasons (e.g. unavailable for follow-up). Thus, 1252 patients initially agreed to participate. Of these, 301 were lost to the survey: 109 died of causes other than hepatitis, 12 were too ill to continue to attend, 40 moved away, 67 could not be traced, and 73 refused to continue. There remained 951 patients who were followed for 6 months, but in 183 of these the follow-up was considered inadequate because intervals between successive visits exceeded 4 weeks on one or more occasions. The remaining 768 patients were studied in detail and completed 6482 of their expected 6912 visits. All the data reported below concern only this final group of 768 patients.

There were 474 women and 294 men. The average age of the women was 42 and of the men 54 years. There were 262 immigrants : West Indies, $125(16 \%)$; Ireland, $48(6 \%)$; India and Pakistan, $38(5 \%)$; other countries, $51(7 \%)$. There were 261 (34\%) general surgical cases, $177(23 \%)$ gynaecological, $147(19 \%)$ general medical, $99(13 \%)$ obstetric and $84(11 \%)$ orthopaedic. At the time of transfusion $80 \%$ of the patients had undergone a surgical operation.

A transfusion was defined as any continuous infusion of blood; $84 \%$ of the patients were thus transfused on one occasion only. The remainder were multiply transfused. Any blood subsequently administered later than 2 months after admission to the survey was ignored in calculating the average units received by each patient. The total number of units of blood transfused was 2824, an average of 
Table 1. Groups of hepatitis patients

$\begin{array}{lccc} & \begin{array}{c}\text { Total } \\ \text { no. }\end{array} & \begin{array}{c}\text { HB Ag } \\ \text { positive }\end{array} & \begin{array}{c}\text { CMV } \\ \text { antibody } \\ \text { response }\end{array} \\ \begin{array}{l}\text { Group I. Hepatitis confirmed by liver } \\ \text { biopsy }\end{array} & 6 & 2 & 0 \\ \begin{array}{c}\text { Group II. Typical clinical and biochemical } \\ \text { features of hepatitis (including icterus); }\end{array} & 2 & 2 & 0 \\ \quad \text { liver biopsy not done } & & & \\ \text { Group III. Raised serum ALT without } & & 2 & 0 \\ \text { other clinical features of hepatitis } \\ \text { (a) liver biopsy did not confirm } \\ \quad \text { hepatitis }\end{array}$

$3 \cdot 7$ units per patient. Forty-eight patients $(6 \cdot 3 \%)$ also received plasma or other blood products, none of which had been tested for the presence of $\mathrm{HB} \mathrm{Ag}$ : these patients were excluded from the calculation of the incidence of post-transfusion hepatitis.

The mean duration of stay in hospital was 26 days with a range of 2-212 days.

\section{Hepatitis patients}

One hundred and fifty-eight patients developed raised serum ALT values after transfusion. These patients were investigated for conditions other than viral hepatitis (e.g. drug-induced liver injury) that might have caused the ALT rises. It was arbitrarily decided that where such other potential causes existed, the patient would not be regarded as suffering from viral hepatitis. Hepatitis, either icteric or anicteric, was judged to be present in eight patients $(1.0 \%)$; sustained elevation of ALT without other clinical features of hepatitis was present in another $35(4 \cdot 6 \%)$ patients. The results are summarized in Table 1.

\section{Group I}

This group comprised four males aged $27,60,65$ and 69 years who received 4, 8 , 17 and 6 units of blood respectively, and two females aged 39 and 47 years who received 2 and 4 units of blood respectively. All showed typical histological features of acute hepatitis. Two had received HB Ag positive blood and themselves became HB Ag positive. Both developed jaundice; one died, the other patient made a full recovery after an illness lasting 8 weeks. Four patients remained HB Ag negative; one developed jaundice and showed massive necrosis on biopsy and three were anicteric. The three anicteric patients recovered fully after ALT rises lasting 2 and 3 weeks and 6 months respectively. The patient with massive necrosis had persistent biochemical changes and hepatic abnormalities which were still demonstrable at 18 months, when biopsy showed inactive macronodular cirrhosis. The incubation periods to the first observed ALT rise were 2, 6, 7 (2 patients), 8 and 11 weeks respectively. 


\section{Group II}

Both patients in this group showed clinical features consistent with viral hepatitis. A 66-year-old man became HB Ag positive 10 weeks after transfusion with six units of blood. One week later his ALT value was 2950 i.u./l. and he died within a few days with fulminating hepatic failure. Consent for post-mortem examination was not obtained. A 25-year-old man became HB Ag positive with an ALT value of 1400 i.u./l. 14 weeks after the transfusion with 19 units of blood and one unit of plasma. He was lethargic, anorexic and jaundiced but recovered fully after an illness lasting 6 weeks. Biopsy was not performed because of a history of bleeding after previous surgical procedures.

\section{Group III}

The 35 patients in this group showed conspicuous or sustained serum ALT rises, which in seven were greater than $100 \mathrm{i} . u$./l. In two of these seven and in three of the other patients, the serum bilirubin was between 1 and $2 \mathrm{mg} . / 100 \mathrm{ml}$. However, none had symptoms or physical signs suggestive of viral hepatitis. The group consisted of 13 men aged between 23 and 68 (mean age 47 years) and 22 women aged between 22 and 67 years (mean age 43 years). These patients received between 1 and 21 units of blood (mean 3.9 units). Two of them also received one and 19 units of plasma respectively. Six patients underwent liver biopsy within 7 days of the ALT rise, but none had ALT values above 100 i.u./l., though all had abnormal BSP retention and one had a serum bilirubin of $2 \cdot 0 \mathrm{mg} . / 100 \mathrm{ml}$. None showed the histological features typical of acute viral hepatitis. Two of them were $\mathrm{HB} \mathrm{Ag}$ positive, but in both the blood transfused was HB Ag negative, as it was in the other four patients who were biopsied; one of the latter had also received plasma.

The remaining 29 patients were unwilling to undergo liver biopsy. Two received HB Ag positive blood, but neither developed positive antigen tests: one had an ALT value of 260 i.u./1. 5 weeks after transfusion with raised serum bilirubin and alkaline phosphatase concentrations and marked BSP retention; the other had an AL'T value of 47 i.u./l. 5 weeks after transfusion and subsequently became $\mathrm{HB} \mathrm{Ab}$ positive. Two other patients became HB Ag positive with simultaneous ALT rises 7 and 24 weeks respectively after transfusion, but the blood transfused was $\mathrm{HB} \mathrm{Ag}$ negative. Thus, in six of the 35 patients the presence of $\mathrm{HB} \mathrm{Ag}$ in either the blood transfused or the recipient was associated with ALT rises in the recipient's serum; liver biopsies done in two of these recipients, however, failed to show hepatitis. One further patient in the non-biopsied group also received plasma but remained $\mathrm{HB}$ Ag negative. Among the remaining 24 patients were four in whom the ALT rises were associated with the appearance of CMV antibody and one in whom a CMV antibody booster response occurred. None of these five patients became $\mathrm{HB} \mathrm{Ag}$ positive and the blood transfused was $\mathrm{HB} \mathrm{Ag}$ negative. None showed clinical evidence of the post-perfusion syndrome, i.e. fever, lymphocytosis, lymphadenopathy and hepatosplenomegaly were not observed. 


\section{Other patients showing $A L T$ rises}

The residual 115 patients who showed ALT rises after transfusion were thought not to have viral hepatitis, although liver biopsies showed features akin to hepatitis in five of these. Halothane was accepted as the cause in these five cases; the onset of the hepatitis was 2 weeks after transfusion in four and 10 weeks after transfusion (but one week after a third exposure to Halothane) in the fifth. One case relapsed on re-exposure to Halothane. Liver biopsy showed focal liver-cell necrosis in a sixth patient who had received Halothane; this patient also showed a CMV antibody booster response. Halothane was also thought to be responsible for ALT rises in two further patients who were not biopsied.

Drugs or alcohol were accepted as the cause of ALT rises in nine patients. Liver biopsy showed evidence of recent liver-cell necrosis or cholestasis in one of these following oral contraceptive drugs. The biopsy of a second patient who had received chlordiazepoxide showed only siderosis and mild non-specific reactive changes. A third biopsy in an alcoholic patient showed fatty change.

Acceptable reasons for ALT rises were present in 27 patients. Liver biopsy showed abnormalities other than hepatitis in three (fatty change in one, nonspecific inflammation in one, primary biliary cirrhosis in one). The primary clinical condition of the patient was felt to provide adequate reason for the ALT rises in ten patients with carcinomatosis, five with severe sepsis, four with pulmonary embolism, two with hepatic cirrhosis, one with acute pancreatitis, one with acute ulcerative colitis and one with gallstones.

Fifty patients showed ALT rises 2 weeks after transfusion. In many, the value had returned to normal a week later and in the remainder, with the exception of four, the value was normal within 2 weeks. In these four patients the test could not be repeated for 4 weeks; the values were then found to be normal. All but five of these patients had been recently operated upon and the ALT rises may have been the non-specific effect of the surgical procedure. However, a primary CMV antibody response occurred in one and booster responses in three of these surgical patients.

The remaining 21 ALT rises occurred at longer intervals after transfusion; these, too, had returned to normal again within one week. Biopsy was done after one such rise occurring 4 weeks after transfusion; the histology was normal. An increase in pre-existing CMV antibody titre followed an enzyme rise occurring 6 weeks after transfusion in another.

No clinical case of post-perfusion syndrome was seen.

\section{Liver biopsies}

Liver biopsy was performed in 25 patients. In six the lesions of typical acute hepatitis were found. In a further six, in whom hepatitis had been suspected clinically, convincing histological evidence was not found, though two of the patients were HB Ag positive; any histological changes present in these six cases were very slight, ranging from mild sinusoidal congestion to occasional focal liver-cell necrosis. The biopsy appearances in 12 patients, whose raised ALT values were thought to 


\section{Table 2. Summary of $H B A g$ and $H B$ Ab results}

$\begin{array}{lccc} & \begin{array}{c}\text { No. } \\ \text { tested }\end{array} & \begin{array}{c}\text { HB Ag } \\ \text { positive }\end{array} & \begin{array}{r}\text { HB Ab } \\ \text { positive }\end{array} \\ \text { Transfused patients } & 768 & 13(1 \cdot 69) & 7(0 \cdot 91) \\ \text { Blood donors } & 8953 & 13(0 \cdot 15) & 8(0 \cdot 09) \\ \text { Control patients } & 1489 & 5(0 \cdot 34) & 7(0 \cdot 47)\end{array}$

Figures in parentheses indicate percentages.

age 48 years). They comprised 606 general medical, 181 general surgical, 457 orthopaedic and 245 obstetrical and gynaecological patients. Raised ALT values were found in 42. Adequate explanations for these, other than hepatitis, such as congestive heart failure, were present in 20. In another five patients ALT returned to normal within one week. In a further six, liver biopsies did not confirm a diagnosis of hepatitis. The remaining 11 cases possibly did have hepatitis; one was confirmed by liver biopsy, three others became HB Ag positive, and one became $\mathrm{HB} \mathrm{Ab}$ positive.

HB Ag was found in five control patients (0.3\%) including the three with ALT rises mentioned above; the other two appeared to be symptomless carriers.

HB Ab was found in seven control patients. One initially had a raised ALT (see above) which may have been due to hepatitis. Another had a long standing hepatosplenomegaly of unknown cause with normal liver function tests, and the remaining five were clinically normal.

The findings with respect to $\mathrm{HB} \mathrm{Ag}$ and $\mathrm{HB} \mathrm{Ab}$ in transfused patients, blood donors and control patients are summarized in Table 2. The difference in the frequency of antigen in the transfused patients on the one hand and the control patients and blood donors on the other is significant at the $1 \%$ level. The difference in frequency of antigen between the control patients and blood donors is not significant. There is also a statistically significant difference in the frequency of antibody between transfused patients and the blood donor population, but not between transfused and control patients.

\section{Cytomegalovirus and Epstein-Barr virus infections}

Serial serum specimens were available for testing in 712 of the 768 patients: there were 270 men and 442 women.

CMV primary infections: 270 patients $(38 \%)$ had no detectable CMV antibody before transfusion. Twenty-four of these (9\%) acquired antibody after transfusion. Thirteen were women, mean age 39 years, and eleven were men, mean age 57 years. They had received between one and 14 units of blood (mean 4.4 units). Antibody appeared 4 weeks after transfusion in 15 patients, after 6 weeks in two, after 10 weeks in four, and after 12 and 24 weeks respectively in two. The time of conversion is not known for one patient whose intermediate sera were not tested. A sustained ALT rise immediately preceded the antibody conversion in three patients and followed it within an interval of 6 weeks in one but the patients showed no other features of hepatitis (in Group III above). Another patient showed a 
have causes other than viral hepatitis have already been mentioned. Biopsy in the remaining patient after an isolated ALT rise was normal.

\section{$H B A g$ and $H B A b$ results}

\section{Recipients of positive donor blood}

Of 8953 units of blood for transfusion, HB Ag was detected in $13(0.15 \%)$, and $\mathrm{HB} \mathrm{Ab}$ in $8(0.09 \%): 2824$ of these were transfused. Five patients in the survey received blood which was subsequently shown to contain HB Ag. Two developed icteric hepatitis with antigenaemia and one of them died. Another developed a persistently raised ALT but antigen was not detected in his serum, and in a further patient $\mathrm{HB} \mathrm{Ab}$ appeared after a minor ALT rise; neither of these patients underwent biopsy. The fifth recipient had an entirely uneventful clinical course and tests for antigen and antibody were both negative. Two patients who received known HB Ab positive blood had an uneventful clinical course.

\section{Prevalence of $H B \mathrm{Ag}$ and $H B A b$ in survey patients}

One patient out of the 768 surveyed was $\mathrm{HB} \mathrm{Ag}$ positive before transfusion and remained a persistent carrier; his liver function tests remained normal.

The antigen became detectable in the blood of 13 other patients, including the two mentioned above who received HB Ag positive blood. Icteric hepatitis occurred in four, two of whom died. Four others showed ALT rises; the remaining five patients had uneventful clinical courses. $\mathrm{HB} \mathrm{Ag}$ was first detected in the serum of these patients at the following intervals after transfusion: after 7 and 10 weeks respectively in the two patients who died; after 4 and 14 weeks respectively in the two icteric patients who recovered; and 2, 4, 7 and 24 weeks respectively in the four patients who showed only raised ALT values. The five patients who had an uneventful clinical course showed antigenaemia 2 weeks (three patients) and 10 weeks (two patients) after transfusion.

HB Ab became detectable in the serum of seven patients $(0.9 \%)$. In one, who had received antigen-positive blood, the appearance of antibody coincided with an ALT rise 5 weeks after transfusion. This patient has been described under Group III above. In five who had received blood which was antigen-negative by the immunodiffusion technique antibody appeared 2,14,15, 19 and 20 weeks respectively after transfusion. The seventh patient received blood which had not been tested for the presence of antigen, and antibody was first detected 4 weeks after the transfusion. These six patients showed no rise in ALT values.

Three patients, who had detectable $\mathrm{HB}$ Ab before transfusion, remained persistent antibody carriers throughout the survey. One of these showed a raised ALT 2 weeks after blood transfusion, possibly attributable to three successive exposures to Halothane. The other two carriers had normal liver function tests. None of these three patients had a past history of transfusion or hepatitis.

\section{Control patients}

Between 1 February and 30 November 1971, 1489 patients agreed to act as controls. There were 716 men (average age 53 years) and 773 women (average 
transient ALT rise 2 weeks after transfusion but the antibody rise in this patient did not occur until at least 12 weeks later. In one patient the antibody appeared after an influenza-like illness during which liver function tests remained normal. The remaining 18 conversions occurred without symptoms or biochemical abnormalities.

CMV antibody booster responses: 442 patients (62\%) had CMV antibodies at the time of transfusion. Thirteen of these $(2.9 \%)$ showed a fourfold increase in antibody titre. There were nine women, mean age 43 years, and four men, mean age 62 years. They had received between one and 12 units of blood (mean $3 \cdot 6$ units). Antibody titres rose after intervals from transfusion of 4 weeks (three patients), 6 weeks (two patients), 8 weeks (two patients) and 10 weeks (four patients). In two, the exact time of the rise in titre was not determined. These booster responses occurred predominantly in patients with low initial antibody titres; they were not found in patients with initial titres of $1 / 128$ or more. One of these patients developed an ALT value of 36 i.u./1. 6 weeks after transfusion and the changes persisted for 4 weeks (Group III above). Four others showed transient ALT rises, 2 weeks after transfusion in three patients, and 6 weeks after in one; the antibody booster responses in these four patients occurred 2, 4, 6 and 6 weeks after the ALT rise. One further patient had shown conspicuous elevations of ALT before a rise in CMV antibody titre, but these were thought to have been caused by Halothane; biopsy revealed a focus of liver-cell necrosis. The remaining seven patients with booster responses had neither symptoms nor biochemical abnormalities.

Persistent abnormalities of liver function, without other evident cause, were thus demonstrated in five of the 37 patients undergoing either primary CMV infection or CMV reinfection; five showed transient ALT abnormalities.

EBV primary infection: 55 patients $(7.7 \%)$ had no EBV antibody before transfusion. Three of these $(5.5 \%)$ developed antibody after intervals from transfusion of 2,2 and 24 weeks respectively. No disturbance of liver function or clinical illness developed in these patients. A fourth patient, who showed an EBV antibody conversion after 10 weeks, had intermittent ALT rises throughout the survey; these might have been caused by alcohol or treatment with antidepressant drugs.

EBV booster responses: 657 patients had EBV antibody before transfusion. Only one of these showed a fourfold increase in titre 4 to 6 weeks after a transient rise which occurred 4 weeks after transfusion.

Thus there was serological evidence of EBV infection in five patients.

\section{DISCUSSION}

The overall incidence of icteric and anicteric hepatitis in the present survey $(1.0 \%)$ is low compared with the incidence found in prospective studies in Japan (65\%, Shimizu \& Kitamoto, 1963), U.S.A. (18\%, Hampers, Prager \& Senior, 1964), and Germany (14\%, Creutzfeldt et al. 1966). It is important to consider whether this difference is real, resulting, for example, from a lower incidence of carriers of hepatitis B virus in the donor population, or apparent because of the 
differences in the patient populations studied or in the criteria used in diagnosing hepatitis.

The only exclusion of patients in the present survey was made on the basis of extremes of age or unwillingness to co-operate. With regard to the latter no important differences in terms of age, sex, primary diagnosis, country of origin, previous liver disease, recent contact with jaundiced persons, injections received outside the hospital, recent travel abroad or the survey month in which they were transfused were found between patients in the trial group and those who were omitted. Nor was there any significant difference in the volume of blood received by these two groups. There is therefore no reason for assuming that the omitted group might have been at greater risk of developing hepatitis. Overcrowding and poor social conditions are not uncommon in the background of the patients studied. Cherubin (1971) has drawn attention to the low incidence of hepatitis in a Harlem hospital despite the use of commercial blood. He attributed this to immunity resulting from exposure to hepatitis $B$ virus in a lower socio-economic urban community.

Criteria used for the diagnosis of hepatitis are next considered. Liver biopsy may provide incontrovertible confirmatory evidence of hepatitis but this procedure is seldom undertaken. When liver biopsy was not performed, that is to say in the majority of the survey patients, reliance was placed on clinical evidence and measurement of serum ALT. The duration and degree of elevation of the enzyme that qualify a patient for inclusion in the hepatitis group must be critically examined. Neither a rise in ALT, nor its magnitude, is a specific indication of hepatitis. In some previous surveys a transaminase level was arbitrarily defined below which a diagnosis of hepatitis was not made. Shimizu \& Kitamoto (1963) required the ALT to reach a value greater than 90 units (normal $<40$ units) and to remain above 50 units for at least 2 weeks. Hampers, Prager \& Senior (1964) required elevations of at least three standard deviations above the mean on at least two occasions. Katz, Rodriguez \& Ward (1971) in Chile adopted an ALT > 100 units for more than 10 days as indicating hepatitis. In the present survey no such arbitrary lower limit was set. However, if other factors were present which might have caused the enzyme rise these patients were not considered to be suffering from viral hepatitis; it was accepted that these other factors were a more likely cause of the liver damage. These included such important categories as underlying hepatobiliary disease and the administration of potentially hepatotoxic drugs. This rigid exclusion of all patients having other possible causes for their liver damage may have contributed to the low incidence of hepatitis in the present study.

Another factor which must be considered in this context is the fact that only 25 $(29 \%)$ of the 87 patients with sustained ALT rises underwent liver biopsy and this is the conclusive way in which hepatitis can be proved. In the absence of histological proof, the significance of conversion to $\mathrm{HB} \mathrm{Ag}$ positivity in conjunction with an ALT rise was regarded as evidence of viral liver damage only in two patients who developed a frank clinical jllness. Without the latter the relationship is more speculative and histological studies in two such patients failed to reveal any hepatitis. These cases were therefore also excluded from the hepatitis group. 
Similarly, ALT rises alone were not regarded as providing sufficient evidence of hepatitis.

The techniques used during the survey for detecting $\mathrm{HB} \mathrm{Ag}$ and $\mathrm{HB} \mathrm{Ab}$ were not as sensitive as those now available, e.g. radioimmunoassay, and therefore the figures now reported probably underestimate the frequency of antigen and antibody. The results of examination by radioimmunoassay of the specimens collected in the survey, all of which were stored frozen, will be published later.

A further possible cause of underestimation of the incidence of post-transfusion hepatitis must lastly be considered. During the last five months of the survey the blood used for transfusion had been screened for HB Ag by the immunodiffusion technique and $23 \%$ of the patients received such blood. Of the eight patients with hepatitis five, including two who became antigen positive and one of whom died, developed hepatitis after the screening programme began at the Regional Transfusion Centre. The risks still attached to transfusing screened blood have been stressed by Alter et al. (1972). The sensitivity of screening tests and the possible role played by different subtypes of hepatitis B virus in causing liver damage attributable to blood transfusion may be important.

Somayaji, Stone \& Glover (1967) reported a prospective study in which 45 patients were surveyed, including measurement of serum transaminases, for 22 weeks after transfusion. Only two showed a transient elevation of serum enzymes; liver biopsy on one of these showed normal liver tissue. The authors concluded that none of the 45 patients developed hepatitis. The main evidence for the incidence of post-transfusion hepatitis after blood transfusion in the U.K. is derived from three prospective studies, in which the occurrence of jaundice was the criterion by which the diagnosis of hepatitis was made; Spurling, Shone \& Vaughan (1946) found six $(0.7 \%)$ cases of jaundice among 891 patients but these were considered 'doubtful if due to transfusion'; Lehane, Kwantes, Upward \& Thomson (1949) observed 22 cases $(0.8 \%)$ among 2796 patients; in a joint survey organized on behalf of Ministry of Health, Medical Research Council and Department of Health for Scotland (Ministry of Health, 1954), there were four cases $(0 \cdot 16 \%)$ of jaundice among 2538 patients in England and Wales and five $(0.36 \%)$ among 1387 patients in Scotland.

The low incidence of hepatitis in the present study must also be considered in the light of transfusion procedures in different countries. Evidence from the United States indicated that blood obtained from paid donors carried a greater risk of transmitting hepatitis in the recipient than blood from unpaid volunteers (Allen et al. 1959; Grady \& Chalmers, 1964; Walsh et al. 1970). In the present study blood from unpaid donors was exclusively used. Nevertheless, although the incidence of hepatitis was small there was a morbidity and mortality equivalent to 27 cases of hepatitis, including eight deaths, per 10,000 units of blood transfused in patients receiving blood only.

The frequency of CMV and EBV antibodies in the hospital population studied here was similar to that found previously for the same age groups in London (Stern \& Elek, 1965; Pereira, Blake \& Macrae, 1969). Although the risk of infection with these viruses, after blood transfusion, is greater with fresh blood (Paloheimo et al. 
1968) the present investigation confirms that infection can be transmitted by blood stored for several days (Stevens, Barker, Ketcham \& Meyer, 1970; Prince, Szmuness, Millian \& David, 1971). Although most infections are primary ones in patients without antibody, reinfections or reactivations of latent infections do occur, particularly in patients with low titres of pre-existing antibody. Nearly all of these infections are symptomless.

The Working Party is indebted to:

Dr R. Lendrum, Dr C. McGavin, Dr P. J. Davies and Dr P. Kullavanijaya for the collection of clinical data.

Dr J. G. Walker for assistance with the clinical supervision of the survey.

Dr. G. Discombe and Dr H. S. Wiggins for biochemical advice.

Dr Patricia Taylor for assistance with investigation of the serology of $\mathrm{HB} A g$ and $\mathrm{HB} \mathrm{Ab}$.

Professor H. Stern for investigation of the serology of cytomegalovirus and Epstein-Barr virus.

Dr P. J. Scheuer for examination of liver biopsy specimens.

Dr R. M. Greenwood and Mr I. D. Hill for statistical assistance.

Mrs P. M. Evans for assistance with administration of the survey.

The Working Party's thanks are also due to the medical and nursing staff of the Central Middlesex Hospital, the staff of the North London Blood Transfusion Centre, and the staff of the Hepatitis Research Unit, London School of Hygiene and Tropical Medicine.

Members of the Working Party were Dr D. R. Bangham, Dr J. T. Boyd, Dr. T. E. Cleghorn, Dr Y. E. Cossart, Professor D. G. Evans, Dr Jean Grant, Sir Francis Avery Jones, Dr F. O. MacCallum, Dr W. d'A. Maycock (Chairman), Professor T. A. J. Prankerd, Professor Sheila Sherlock, Dr C. C. Spicer, Dr F. Stratton, Dr J. Wallace and Professor A. J. Zuckerman (Secretary).

The Report was prepared by Dr R. Lendrum, Dr J. G. Walker, Dr W. d'A. Maycock, Professor H. Stern, Dr Patricia Taylor and Professor A. J. Zuckerman.

\section{REFERENCES}

Allen, J. G., Dawson, D., Sayman, W. A., Humpereys, E. M., Denham, R. S. \& Havens, I. (1959). Blood transfusions and serum hepatitis. Use of monochloroacetate as an antibacterial agent in plasma. Annals of Surgery 150, 455-68.

Auter, H. J., Holland, P. V., Purcelr, R. H., Lander, J. J., Feinstone, S. M., Morrow, A. G. \& Schmidt, P.J. (1972). Post-transfusion hepatitis after exclusion of commercial and hepatitis-B antigen-positive donors. Annals of Internal Medicine 77, 691-9.

BergmeYer, H. U. \& Bernt, E. (1963). Glutamate-pyruvate transaminase. In Methods of Enzymatic Analysis, pp. 846-51. New York and London: Academic Press.

Blumbera, B. S., Gerstlex, B.J. S., Hungerford, D. A., London, W.T. \& Sutnick, A. I. (1967). A serum antigen (Australia antigen) in Down's syndrome, leukemia and hepatitis. Annals of Internal Medicine 66, 924-31.

Bowers, G. N. \& MсСомв, R.B. (1966). A continuous spectrophotometric method for measuring the activity of serum alkaline phosphatase. Clinical Chemistry 12, 70-89.

Cherubin, C. E. (1971). The risk of post-transfusion hepatitis in recipients of blood containing SH antigen at Harlem Hospital. Lancet i, 627-30. 
Creutzfeldt, W., Severidt, H. J., Schmitt, H., Gallasch, E., Arndt, H. J., Brachmann, H., Schmidt, G. \& Tschaepe, U. (1966). The incidence and course of icteric and anicteric transfusion hepatitis. German Medical Monthly 11, 469-76.

Epstein, M. A., Achong, B. G. \& Barr, Y. M. (1964). Virus particles in cultured lymphoblasts for Burkitt's lymphoma. Lancet i, 762-3.

Grusti, G., Ruggiero, G. \& Cacciatore, L. (1969). A comparative study of some spectrophotometric and colorimetric procedures for the determination of serum glutamic-oxalo. acetic and glutamic-pyruvic transaminase in hepatic diseases. Enzymologia Biologica et Clinica 10, 17-38.

Grady, G. F., Chalmers, T. C. \& The Boston Inter-Hospital Liver Group (1964). Risk of post-transfusion viral hepatitis. New England Journal of Medicine 271, 337-42.

Hampers, C. L., Prager, D. \& Senior, J. R. (1964). Post-transfusion anicteric hepatitis. New England Journal of Medicine 271, 747-54.

Henle, G. \& Hente, W. (1966). Immunofluorescence in cells derived from Burkitt's lymphoma. Journal of Bacteriology 91, 1248-56.

Henle, G., Henle, W. \& Dient, V. (1968). Relation of Burkitt's tumour-associated herpestype virus to infectious mononucleosis. Proceedings of the National Academy of Sciences of the U.S.A. 59, 94-101.

Henle, W., Henle, G., Scriba, M., Joyner, C. R., Harrison, F. S., Von Essen, R., Palohermo, J. \& Klemola, E. (1970). Antibody responses to the Epstein-Barr and cytomegaloviruses after open-heart and other surgery. New England Journal of Medicine 282, 1068-74.

Katz, R., Rodriguez, J. \& Ward, R. (1971). Post-transfusion hepatitis: effect of modified gamma-globulin added to blood in vitro. New England Journal of Medicine 285, 925-32.

Lehane, D., Kwantes, C. M. S., Upward, M. G. \& Thomson, D. R. (1949). Homologous serum jaundice. British Medical Journal ii, 572-4.

MCCollum, R. W. \& ZUCKerman, A. J. (1970). Application of laboratory methods. Tests for Australia (hepatitis-associated) antigen and antibody. Bulletin of the World Health Organization 42, 987-92.

Ministry of Health (1954). Homologous serum jaundice after transfusion of whole blood, dried small-pool plasma, dried irradiated plasma and kaolin-treated filtered liquid plasma. Lancet i, 1328-9.

Paloheimo, J. A., Von Essen, R., Klemola, E., Kankiaken, L. \& Siltanen, P. (1968). Subclinical cytomegalovirus infections and cytomegalovirus mononucleosis after openheart surgery. American Journal of Cardiology 22, 624-30.

Pereira, M. S., Blake, J. M. \& Macrae, A. D. (1969). EB Virus antibody at different ages. British Medical Journal iv, 526-7.

Prince, A. M. (1968). An antigen detected in the blood during the incubation period of serum hepatitis. Proceedings of the National Academy of Sciences of the U.S.A. 60, 814-21.

Prince, A. M., Szmuness, W., Mirlian, S. J. \& David, D. S. (1971). A serologic study of cytomegalovirus infections associated with blood transfusions. New England Journal of Medicine 284, 1125-31.

Reitman, S. \& Franket, S. (1957). A colorimetric method for the determination of serum glutamic oxaloacetic and serum glutamic-pyruvic transaminases. American Journal of Clinical Pathology 28, 56-63.

Shimizu, Y. \& Kiтamoto, O. (1963). The incidence of viral hepatitis after blood transfusions. Gastroenterology 44, 740-4.

SomayaJi, B. N., Stone, W. D. \& GLover, P. B. (1967). Risk of anicteric hepatitis following blood transfusion. Gut, 8, 614-17.

SpURling, N., Shone, J. \& VAUghan, J. (1946). The incidence, incubation period and symptomatology of homologous serum jaundice. British Medical Journal ii, 409-12.

StERN, H. \& EleK, S. D. (1965). The incidence of infection with cytomegalovirus in a normal population. A serological study in Greater London. Journal of Hygiene 63, 79-87.

Stevens, D. P., Barker, L. F., Ketcham, A. S. \& Meyer, H. M. Jr. (1970). Asymptomatic cytomegalovirus infection following blood transfusion in tumor surgery. Journal of the American Medical Association 211, 1341-4.

TAYLOR, P. E. (1970). Viral hepatitis and tests for the Australia (hepatitis-associated) antigen and antibody. IV. Complement fixation tests. Bulletin of the World Health Organization 42, 966-73. 
Walsh, J. H., Purcell, R. H., Morrow, A. G., Chanock, R. M. \& Schmidt, D. J. (1970). Post transfusion hepatitis after open-heart operations. Incidence after the administration of blood from commercial and volunteer donor populations. Journal of the American Medical Association 211, 261-5.

ZuCKERMAN, A. J. (1970a). In Virus Diseases of the Liver. London: Butterworth.

Zuckerman, A. J. (1970b). Viral hepatitis and tests for the Australia (hepatitis-associated) antigen and antibody. VI. Electron microscopy and immune electronmicroscopy. Bulletin of the World Health Organization 42, 975-8.

ZUCKerman, A. J. (1972). In Hepatitis-associated Antigen and Viruses. Amsterdam: North Holland Publishing Company.

Zuckerman, A.J. \& TAYlor, P. E. (1969). Persistence of serum hepatitis (SH-Australia) antigen for many years. Nature, London 223, 81-2. 